\title{
Me-BTABr Reagent in Cloud Point Extraction for Spectrometric Determination of Copper in Water Samples
}

\author{
Valfredo A. Lemos, ${ }^{*}$ Juracir S. Santos and Patrícia X. Baliza \\ Laboratório de Química Analítica (LQA), Universidade Estadual do Sudoeste da Bahia, \\ Campus de Jequié, 45200-000 Jequié-BA, Brazil
}

\begin{abstract}
Neste trabalho, é proposto um novo método para a determinação de cobre, utilizando extração em ponto-nuvem. O reagente 2-[2`-(6-metil-benzotiazolilazo)]-4-bromofenol (Me-BTABr) foi usado como agente complexante e Triton X-114 foi adicionado como surfactante. Após a separação das fases, foi promovida a diluição da fase rica em surfactante com metanol acidificado, e o teor de cobre medido por Espectrometria de Absorção Atômica com chama. O procedimento proposto viabilizou a determinação de cobre com um limite de detecção de $1,08 \mu \mathrm{g} \mathrm{L}^{-1}$. O procedimento foi validado por meio da análise de material de referência certificado. O método foi aplicado com sucesso à determinação de cobre, em amostras de água de rio e poço.
\end{abstract}

A new preconcentration method using cloud point approach is proposed for copper determination. The reagent 2-[2'-(6-methyl-benzothiazolylazo)]-4-bromophenol (Me-BTABr) was used as a complexing agent and Triton X-114 was added as a surfactant. After phase separation, dilution of the surfactant-rich phase with acidified methanol was performed, and the copper content was measured by flame atomic absorption spectrometry. The proposed procedure allowed the determination of copper with detection limit of $1.08 \mu \mathrm{g} \mathrm{L}^{-1}$. The validation of the procedure was carried out by analysis of certified reference material. The method was successfully applied to copper determination in river and well water samples.

Keywords: Me-BTABr, cloud-point extraction, copper, FAAS

\section{Introduction}

Much interest and effort have been devoted on the studies for copper determination in water and biological matrices because it is a good tool for environmental and toxicological monitoring. The removal of copper from aqueous medium such as effluents also is of great interest for environmental and human health purposes. ${ }^{1}$ Generally, the determination of extremely low concentration of this element is associated to separation and preconcentration steps due to insufficient sensitivity or matrix interference. The process involving cloud point extraction (CPE) may be adopted as an alternative to conventional solvent extraction due to a number of possible advantages including attainability of large preconcentration factors and reducing of the consumption of a solvent, disposal costs and extraction time..$^{2-4}$ Moreover, aqueous micellar solutions can replace the more dangerous and toxic organic solvents, allowing to perform the analysis under mild conditions. ${ }^{5,6}$

* e-mail: vlemos@uesb.br
CPE methodology is based on the property of the aqueous solutions of several non-ionic and zwitterionic surfactants, when heated or cooled, to become turbid over a narrow temperature range. This critical temperature, known as the cloud-point temperature (CPT) is based on the surfactant nature and concentration. ${ }^{7}$ If non-ionic surfactants are used, the solution separates into two liquid phases above the cloud point. The concentration of the surfactant-rich phase is the critical micellar concentration. The use of CPE in procedures for separation and preconcentration of metal ions has been centered on the extraction of these metallic substances as sparingly water soluble chelate complexes.

Among various substances used in separation procedures, ${ }^{8}$ including cloud point extraction, pyridylazo and thiazolylazo reagents have been widely employed due several advantages obtained, such as, capacity to form complexes with a large variety of metals and low solubility in water. Some studies indicated that the hydrophobicity of ligands and complexes are the fundamental factors which regulate the extraction efficiency. ${ }^{7,9}$ The first attempt involving the cloud-point 
extraction of ionic species concerned the separation of $\mathrm{Ni}(\mathrm{II})$ TAN [1-(2-thiazolylazo)-2-naphthol] complexes in Triton X100 micellar solutions. ${ }^{10}$ Ligands such as 1-(2-pyridylazo)2-naphthol (PAN), ${ }^{11-14}$ 4-(2-pyridylazo)resorcinol (PAR), ${ }^{11,14}$ 2-(5-bromo-2-pyridylazo)-5-diethilaminophenol (BrPADAP) $)^{11,15,16}$ and 1-(2-thiazolylazo)-2-naphthol (TAN) ${ }^{17,18}$ have been used for cloud point extraction in several procedures.

The present paper describes a new cloud point extraction and preconcentration method for copper by the use of 2-[2'(6-methyl-benzothiazolylazo)]-4-bromophenol (Me$\mathrm{BTABr}$ ) reagent as a complexing agent prior to flame atomic absorption spectrometric determination of this metal. Me$\mathrm{BTABr}$ was firstly synthesised, purified and characterised by our research group and it was used in a flow injection method for zinc determination. ${ }^{19}$ According our knowledge, the use of Me-BTABr or any benzothiazolylazo reagent in analytical procedures involving cloud point extraction has not been reported before.

\section{Experimental}

\section{Reagents}

The laboratory glassware was kept overnight in a 5\% $(\mathrm{v} / \mathrm{v})$ nitric acid solution. Afterwards, it was rinsed thoroughly with deionized water and dried. Deionized water was used to prepare all solutions. All reagents were of analytical reagent grade. Copper working solutions at $\mu \mathrm{g} \mathrm{L}^{-1}$ level were prepared daily by diluting a corresponding $1000 \mu \mathrm{g}$ $\mathrm{mL}^{-1}$ solution (Merck, Darmstadt, Germany). Acetate, borate and ammoniacal buffers were used to adjust the sample $\mathrm{pH}$ in the range of 4.8-6.0, 7.0-8.0 and 9.0, respectively. The non-ionic surfactant Triton X-114 (Sigma-Aldrich, Milwaukee, USA) was used without further purification. Me-BTABr solutions were prepared by dissolving appropriate amounts of 2-[2'-(6-methylbenzothiazolylazo)]-4bromophenol laboratory-prepare ${ }^{19}$ in absolute ethanol (Merck, Darmstadt, Germany). Nitric acid solution was prepared by direct dilution with deionized water from the concentrated solutions (Merck). Methanol and ethanol (Merck, Darmstadt, Germany) were used to decrease the viscosity of surfactant-rich phase.

\section{Apparatus}

A flame atomic absorption spectrometer of the Perkin Elmer Instruments (Shelton, USA) model AAnalyst 200 equipped with air-acetylene flame was used for the analysis. Instrumental conditions used were those suggested by the manufacturer. Also the wavelength had conventional values:

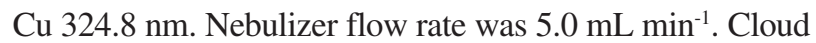
point preconcentration experiments were performed using a thermostated bath (Soc. Fabbe LTDA, São Paulo, Brazil), maintained at the desired temperature and phase separation was assisted using a BIO ENG model BE 5000 centrifuge (São Paulo, Brazil) in $20 \mathrm{~mL}$ centrifuge tubes. A Digimed DM 20 (Santo Amaro, Brazil) pH meter was also used for $\mathrm{pH}$ measurements.

\section{Procedure for cloud point extraction}

Aliquots of $10 \mathrm{~mL}$ of the standard or sample solution containing copper were placed into calibrated $20 \mathrm{~mL}$ cylinders containing $2 \mathrm{~mL}$ of a convenient buffer solution. Me-BTABr $\left(7.0 \times 10^{-5} \mathrm{~mol} \mathrm{~L}^{-1}\right)$ and Triton X-114 (0.05\%, $\mathrm{v} / \mathrm{v})$ solutions were added. This system was placed for 10 min into a thermostated bath at $40{ }^{\circ} \mathrm{C}$. Separation of the two phases was accomplished by centrifugation for $10 \mathrm{~min}$ at $3500 \mathrm{rpm}$. The phases were cooled down in an ice bath in order to increase the viscosity of the surfactant-rich phase. After the cloud point extraction, the aqueous phase was decanted by inverting the tube. To decrease the viscosity of the surfactant-rich phase and facilitate introduction in FAAS nebulizer, $200 \mu \mathrm{L}$ of methanol solution containing $1.0 \mathrm{~mol} \mathrm{~L}^{-1} \mathrm{HNO}_{3}$ was added. The resultant solution was directly introduced into the FAAS by conventional aspiration.

\section{Sample preparation}

For accuracy studies, a certified reference material (CRM) furnished by the National Institute of Standards and Technology (Gaithersburg, MD, USA), NIST 1515 Apple Leaves was analyzed. For their decomposition, ${ }^{19,20}$ about $0.1 \mathrm{~g}$ of material was treated with $4.0 \mathrm{~mL}$ of $1: 1(\mathrm{v} / \mathrm{v})$ nitric acid solution and kept overnight in Teflon vessel. Afterwards the Teflon vessel was closed and put into a pressurized digestion system. The thermal heating was carried out in a stove at $150{ }^{\circ} \mathrm{C}$ for 6 hours. After cooling at room temperature these solutions were adjusted to $\mathrm{pH}$ with a $10 \%(\mathrm{~m} / \mathrm{v})$ sodium hydroxide. The solution was made up to required volume with deionized water into a $25 \mathrm{~mL}$ volumetric flask.

Well and river water samples were collected from the city of Jequié, Bahia state in Brazil. The only pre-treatment was acidification to $\mathrm{pH} 2.0$ with nitric acid, which was performed immediately after collection, in order to prevent adsorption of the metal ions on the flask walls. Samples were filtered before analysis. At least one blank solution was run for each sample in order to evaluate copper contamination by the reagents used. 


\section{Results and Discussion}

Optimum experimental conditions were determined using a $50.0 \mu \mathrm{g} \mathrm{L}^{-1}$ copper solution and investigating parameters affecting the proposed reaction and micelle formation.

\section{Effect of $p H$}

The $\mathrm{pH}$ was the first parameter evaluated on the determination of copper. For this study, acetate, borate and ammoniacal buffers at different $\mathrm{pH}$ values were used. The effect of the sample $\mathrm{pH}$ on the copper response was investigated within the range of $4.7-9.2$. As can be seen in Figure 1, the best interval of $\mathrm{pH}$ for $\mathrm{Cu}$ (II) maximum extraction efficiency was 7.0-8.5. At $\mathrm{pH}$ values below 7.0 the response also decreased because the complexation process is more favorable in weakly basic conditions. In posterior experiments, borate buffer $\mathrm{pH} 7.5$, was chosen as the working $\mathrm{pH}$.

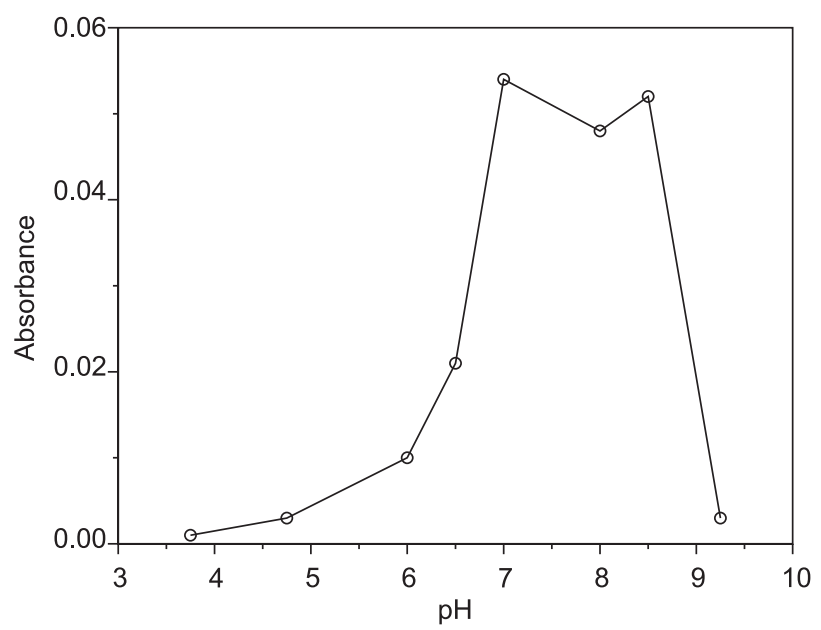

Figure 1. Effect of $\mathrm{pH}$ on the cloud point extraction using $\mathrm{Me}-\mathrm{BTABr}$ reagent for copper determination.

\section{Effect of Me-BTABr concentration}

The effect of the concentrations of the chelating reagent $\mathrm{Me}-\mathrm{BTABr}$ on the analytical response was studied in the range of $4.7 \times 10^{-6}$ to $9.5 \times 10^{-5} \mathrm{~mol} \mathrm{~L}^{-1}$. Results are presented in Figure 2. Higher analytical signals were obtained when used complexing reagent concentrations above or equal $1.9 \times 10^{-5} \mathrm{~mol} \mathrm{~L}^{-1}$. At this initial point of the plateau, a total complexation was attained. Due to consumption of the Me-BTABr caused by its reactivity with other metals, is required the addition of an excess of this chelating reagent. Thus, a $7.0 \times 10^{-5} \mathrm{~mol} \mathrm{~L}^{-1} \mathrm{Me}-\mathrm{BTABr}$ solution was used in subsequent studies.

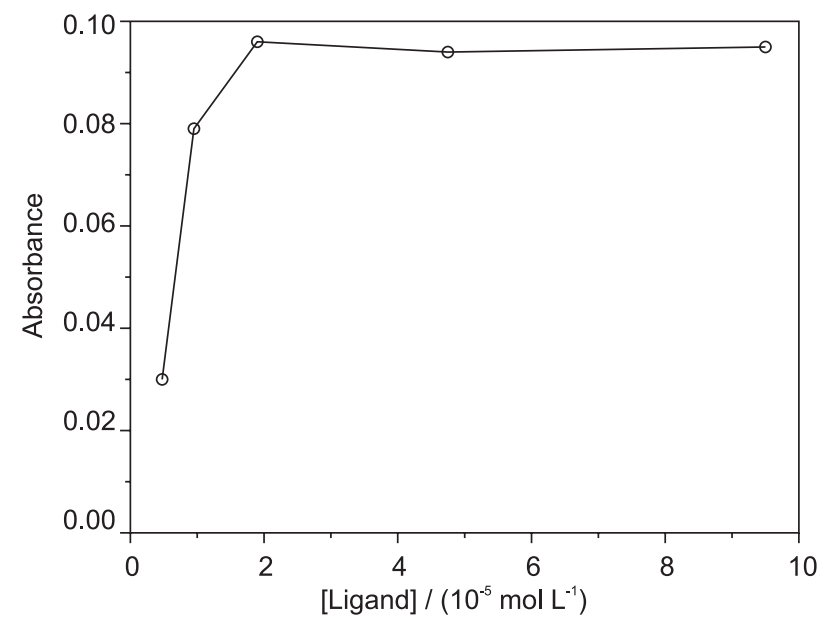

Figure 2. Effect of Me-BTABr concentration on the cloud point extraction for copper determination.

\section{Effect of Triton X-114 concentration}

The effect of surfactant concentration was studied within the Triton X-114 concentration range from $5 \times 10^{-3}$ to $2 \mathrm{x}$ $10^{-1} \%(\mathrm{v} / \mathrm{v})$. The surfactant Triton X-114 was chosen due its commercial availability and low cloud point temperature and high density of the surfactant rich phase, which facilitates phase separation by centrifugation. Figure 3 shows the effect of the surfactant concentration on the analytical signal. The signal is at its maximum when Triton X-114 concentration was $0.05 \%(\mathrm{v} / \mathrm{v})$. At concentrations higher than $0.05 \%(\mathrm{v} / \mathrm{v})$, the analytical signal decreased, probably, due to the increase of the surfactant volume, that deteriorate the FAAS signal. At concentrations below this value, the extraction efficiency of complexes was low because there is few molecules of the surfactant to entrap the $\mathrm{Cu}-\mathrm{Me}-\mathrm{BTABr}$ complex quantitatively. Accordingly, a concentration of $0.05 \%$ Triton $\mathrm{x}-114(\mathrm{v} / \mathrm{v})$ was chosen for use in next experiments.

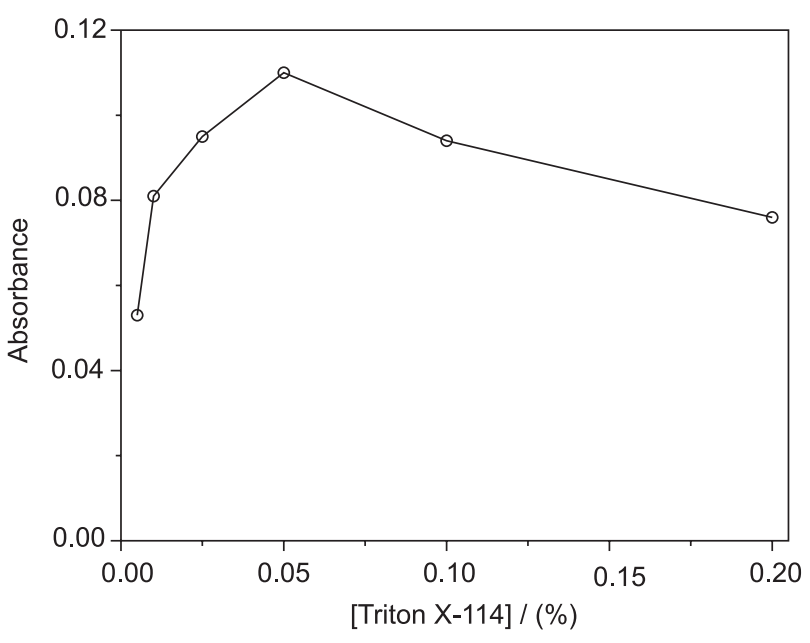

Figure 3. Effect of Triton $\mathrm{X}-114$ concentration on the cloud point extraction for copper determination. 


\section{Effect of incubation temperature and time}

The CPE technique is based on the property of most non-ionic surfactants in aqueous solutions to form micelles and become turbid when heated to cloud point temperature. The effect of the equilibration temperature above the cloud point temperature was investigated within a range of 30 to $60{ }^{\circ} \mathrm{C}$. It was found that an equilibration temperature of 40 ${ }^{\circ} \mathrm{C}$ is adequate to obtain quantitative extraction. The incubation time was a parameter also considered. At $40^{\circ} \mathrm{C}$, it was observed that an equilibration time of $10 \mathrm{~min}$ is sufficient to obtain a good extraction.

\section{Effect of viscosity}

In order to facilitate the sample introduction in the FAAS nebulizer, it was necessary to decrease the surfactantrich viscosity. Several organic solvents and their acid mixtures were investigated, to taking into account that these solvents increase the analytical signal of the FAAS. ${ }^{21}$ Solvents tested include acetone, ethanol and methanol. Best results were obtained using methanol. A $1.0 \mathrm{~mol} \mathrm{~L}^{-1}$ nitric acid solution was added to methanol and $200 \mu \mathrm{L}$ of this solution was used as diluent. In these conditions, the analytical signals were at a maximum.

\section{Analytical features}

Characteristic data under the optimum conditions by preconcentrating $10 \mathrm{~mL}$ of copper were determined and are given in Table 1. Enrichment factors were calculated as the ratio of the slopes of the calibration graphs with preconcentration and direct aspiration, respectively. ${ }^{21}$ By using direct aspiration in FAAS without the preconcentration procedure, the linear equation for copper determination was $\mathrm{A}=5.0 \times 10^{-3}+1.3 \times 10^{-4} \mathrm{C}$, where $\mathrm{A}$ is the absorbance and $\mathrm{C}$ is the copper concentration in solution $\left(\mu \mathrm{g} \mathrm{L}^{-1}\right)$. Other factors that characterize preconcentration systems, such as consumptive index $(\mathrm{CI}),{ }^{21}$ were also determined. The consumptive index is defined as the sample volume, in millilitres, consumed to reach an unit

Table 1. Analytical performance of the cloud point extraction method using Me-BTABr reagent for copper determination

\begin{tabular}{lc}
\hline Enrichment factor & 17 \\
Sample volume, $\mathrm{mL}$ & 10 \\
Consumptive index, $\mathrm{mL}$ & 0.59 \\
Limit of detection, $\mu \mathrm{g} \mathrm{L}^{-1}$ & 1.08 \\
Limit of quantification, $\mu \mathrm{g} \mathrm{L}^{-1}$ & 3.60 \\
Precision $\left(\mathrm{Cu} 50 \mu \mathrm{g} \mathrm{L}^{-1}, \mathrm{n}=7\right), \% \mathrm{RSD}$ & 2.6 \\
Linear range, $\mu \mathrm{g} \mathrm{L}^{-1}$ & $1.08-100$ \\
Calibration function & $\mathrm{A}=8.4 \times 10^{-3}+2.2 \times 10^{-3} \mathrm{C}$ \\
\hline
\end{tabular}

of enrichment factor $(\mathrm{EF})$ : $\mathrm{CI}=\mathrm{V}_{\mathrm{s}}(\mathrm{mL}) / \mathrm{EF}$, where $\mathrm{V}_{\mathrm{s}}$ is the sample volume.

A comparison of the proposed method with other preconcentration procedures for $\mathrm{Cu}$ using several regents is given in Table 4. Compared to relevant CPE studies it can be considered as quite poor. However, the preconcentration factors reported by these studies were usually obtained by using larger sample volumes. In point of fact, the proposed method has a consumptive index lower than the most procedures.

\section{Effect of foreign ions}

A study of potential interferences in the determination of copper was performed. An error of $\pm 5 \%$ in absorbance reading was considered tolerable. Solutions containing copper $\left(50.0 \mu \mathrm{g} \mathrm{L}^{-1}\right)$ and other ions were prepared and the developed procedure was applied. The tolerance limits of various foreign ions are given in Table 2. These results demonstrate that the effects of other ions at given concentrations are negligible. Also, the presence of large amounts of alkali and alkaline earth metals have no significant effect on the preconcentration of copper.

Table 2. Tolerance limit of foreign ions on copper $\left(50 \mu \mathrm{g} \mathrm{L}^{-1}\right)$ determination by proposed procedure

\begin{tabular}{lc}
\hline Substance & Maximum tolerable ion amount \\
\hline $\mathrm{Al}^{3+}$ & $8 \mathrm{mg} \mathrm{L}^{-1}$ \\
$\mathrm{Ca}^{2+}$ & $5 \mathrm{~g} \mathrm{~L}^{-1}$ \\
$\mathrm{Cd}^{2+}$ & $5 \mathrm{mg} \mathrm{L}^{-1}$ \\
$\mathrm{Cl}^{-}$ & $20 \mathrm{~g} \mathrm{~L}^{-1}$ \\
$\mathrm{Co}^{2+}$ & $5 \mathrm{mg} \mathrm{L}^{-1}$ \\
$\mathrm{Cr}^{3+}$ & $15 \mathrm{mg} \mathrm{L}^{-1}$ \\
$\mathrm{Fe}^{3+}$ & $3 \mathrm{mg} \mathrm{L}^{-1}$ \\
$\mathrm{~K}^{2+}$ & $10 \mathrm{~g} \mathrm{~L}^{-1}$ \\
$\mathrm{Mg}^{2+}$ & $5 \mathrm{~g} \mathrm{~L}^{-1}$ \\
$\mathrm{Na}^{+}$ & $20 \mathrm{~g} \mathrm{~L}^{-1}$ \\
$\mathrm{Ni}^{2+}$ & $4 \mathrm{mg} \mathrm{L}^{-1}$ \\
$\mathrm{NO}_{3}^{-}$ & $10 \mathrm{~g} \mathrm{~L}^{-1}$ \\
$\mathrm{~Pb}^{2+}$ & $10 \mathrm{mg} \mathrm{L}^{-1}$ \\
$\mathrm{SO}_{4}{ }^{2-}$ & $500 \mathrm{mg} \mathrm{L}^{-1}$ \\
$\mathrm{Zn}^{2+}$ & $5 \mathrm{mg} \mathrm{L}^{-1}$ \\
\hline
\end{tabular}

Accuracy of the method

In order to study the accuracy of the method, a certified reference material (NIST 1515-Apple Leaves) was analyzed. The copper content obtained (mean $\pm s, n=4$ ) is $5.51 \pm 0.36 \mu \mathrm{g} \mathrm{g}^{1}$ and agree with the certified value (5.64 \pm $\left.0.24 \mu \mathrm{g} \mathrm{g}^{1}\right)$. This result indicate the applicability of the developed procedure in copper determination free of interference. 
Analysis of water samples

The procedure developed was applied to the extraction and determination of copper content from different water samples in order to test its applicability. The results are described in Table 3. According this table, the added copper ions can be quantitatively recovered from the water samples by the proposed procedure. Recoveries $(\mathrm{R})$ of spike additions (5.0 or $10.0 \mu \mathrm{g} \mathrm{L}^{-1}$ ) to water samples were quantitative. $\mathrm{R}$ was calculated as follows: $\mathrm{R}(\%)=\left\{\left(\mathrm{C}_{\mathrm{m}}-\right.\right.$ $\left.\left.\mathrm{C}_{\mathrm{o}}\right) / \mathrm{m}\right\} \times 100$, where $\mathrm{C}_{\mathrm{m}}$ is a value of metal in a spiked sample, $\mathrm{C}_{\mathrm{o}}$ is a value of metal in a sample and $\mathrm{m}$ is the amount of metal spiked. These results demonstrate the applicability of the procedure for copper determination in water samples.

Table 3. Results obtained for copper determination in water samples $(\mathrm{n}=4)$

\begin{tabular}{|c|c|c|c|}
\hline \multirow[t]{2}{*}{ Sample } & \multicolumn{2}{|c|}{ Copper amount $\left(\mu \mathrm{g} \mathrm{L}^{-1}\right)$} & \multirow[t]{2}{*}{ Recovery $(\%)$} \\
\hline & Added & Found* & \\
\hline River water & 0.0 & $3.25 \pm 0.19$ & - \\
\hline \multirow[t]{2}{*}{ Sample 1} & 5.0 & $8.33 \pm 0.36$ & 102 \\
\hline & 10.0 & $12.87 \pm 0.22$ & 96 \\
\hline River water & 0.0 & $5.36 \pm 0.27$ & - \\
\hline \multirow[t]{2}{*}{ Sample 2} & 5.0 & $10.18 \pm 0.41$ & 96 \\
\hline & 10.0 & $15.76 \pm 0.33$ & 104 \\
\hline Well water & 0.0 & $2.87 \pm 0.17$ & - \\
\hline \multirow[t]{2}{*}{ Sample 1} & 5.0 & $8.16 \pm 0.07$ & 106 \\
\hline & 10.0 & $13.69 \pm 0.42$ & 108 \\
\hline Well water & 0.0 & $<$ LOD & - \\
\hline \multirow[t]{2}{*}{ Sample 2} & 5.0 & $4.94 \pm 0.08$ & 99 \\
\hline & 10.0 & $9.32 \pm 0.34$ & 93 \\
\hline
\end{tabular}

* Confidence interval 95\%; LOD: Limit of detection.

Table 4. Procedures using cloud point extration prior copper determination

\begin{tabular}{|c|c|c|c|c|c|c|c|c|}
\hline Reagent & Surfactant & $\mathrm{EF}$ & $\begin{array}{l}\text { Sample volume } \\
(\mathrm{mL})\end{array}$ & $\mathrm{CI}(\mathrm{mL})$ & $\begin{array}{c}\text { LOD } \\
\left(\mu \mathrm{g} \mathrm{L}^{-1}\right)\end{array}$ & Sample & Detection & Ref. \\
\hline TAN & Triton X-114 & 64.3 & 50 & 0.78 & 0.27 & $\begin{array}{c}\text { Standard reference } \\
\text { material }\end{array}$ & FAAS & [17] \\
\hline $\begin{array}{l}\text { Monocarboxylic } \\
\text { aromatic and fatty } \\
\text { row acids }\end{array}$ & $\begin{array}{c}\text { Polyoxyethylated } \\
\text { phenol (OP-10) }\end{array}$ & - - & 100 & -—- & 10.0 & Water & FAAS & {$[22]$} \\
\hline$O, O$-DDTP & Triton X-100 & 33.3 & 10 & 0.30 & 0.94 & $\begin{array}{l}\text { Drinking and rainwater, } \\
\text { serum and human hair }\end{array}$ & FAAS & {$[23]$} \\
\hline PAN & Triton X-114 & 16.3 & 10 & 0.61 & 0.26 & $\begin{array}{c}\text { Tap water, snow water, } \\
\text { and flavor wines }\end{array}$ & $\mathrm{CE}$ & {$[24]$} \\
\hline$A-O, O$-DDTP & Triton X-114 & $17^{a} 16^{b}$ & 40 & $2.35^{\mathrm{a}} 2.50^{\mathrm{b}}$ & 0.03 & $\begin{array}{c}\text { Riverine water, } \\
\text { sea water and enriched } \\
\text { water reference materials }\end{array}$ & ICP-MS & {$[25]$} \\
\hline Me-BTABr & Triton X-114 & 17 & 10 & 0.59 & 1.08 & River and well water & FAAS & is work \\
\hline
\end{tabular}

EF: enrichment factor; CI: consumptive index; LOD: limit of detection; TAN: 1-(2-thiazolylazo)-2-naphthol; PAN: 1-(2-pyridylazo)-2-naphthol; $O, O$-DDTP: $O, O$-diethyldithiophosphate; $A$-O,O-DDTP: ammonium $O, O$-diethyl-dithiophosphate; Me-BTABr: 2-[2'-(6-methylbenzothiazolylazo)]-4-bromophenol; a ${ }^{63} \mathrm{Cu}$; ${ }^{\text {b }}{ }^{65} \mathrm{Cu}$; FAAS: Flame Atomic Absorption Spectrometry; ICP-MS: Inductively Coupled Plasma Mass Spectrometry; CE: Capillary Electrophoresis.
Conclusions

$\mathrm{Me}-\mathrm{BTABr}$ reagent was successfully applied to preconcentration and determination of copper employing cloud point extraction. The procedure improved significantly the performance of the FAAS detection. The use of $\mathrm{Me}-\mathrm{BTABr}$ reagent for preconcentration and determination of copper using CPE shows interesting features. The procedure is very economical, because it consists of much low equipment and running costs and shows also simplicity in apparatus and manipulation. Me$\mathrm{BTABr}$ proved to be promising for application in preconcentration procedures involving different techniques, such as solid-phase extraction, coprecipitation and cloud-point extraction.

\section{Acknowledgments}

Authors acknowledge the financial support of the Conselho Nacional de Desenvolvimento Científico e Tecnológico (CNPq) and Fundação de Amparo à Pesquisa do Estado da Bahia (FAPESB).

\section{References}

1. Sant'Ana, O. D.; Jesuíno, L. D.; Cassella, R. J.; Carvalho, M. B.; Santelli, R. E.; J. Braz. Chem. Soc. 2003, 14, 728.

2. Safavi, A.; Abdollahi, H.; Nezhad, M. R. H.; Kamali, R.; Spectrochim. Acta, Part A 2004, 60, 2897.

3. Nascentes, C. C.; Arruda, M. A. Z.; Maniasso, N. ; Quim. Nova 2002, 25, 483.

4. Ohashi, A.; Tsuguchi, A.; Imura, H.; Ohashi, K.; Anal. Sci. 2004, 20, 1091. 
5. Pramauro, E.; Prevot, A. B.; Pure Appl. Chem. 1995, 4, 551.

6. Manzoori, J. L.; Nezhad, G. K.; Anal. Chim. Acta 2004, 521, 173.

7. Rosen, M. J.; Surfactants and Interfacial Phenomena, John Wiley: New York, 1987.

8. Sant'Ana, O. D.; Jesuíno, L. D.; Cassella, R. J.; Carvalho, M. B.; Santelli, R. E.; J. Braz. Chem. Soc. 2004, 15, 96.

9. Cavasino, F. P.; Sbriziolo, C.; Pelizzetti, E.; Pramauro, E.; J. Phys. Chem. 1989, 93, 469.

10. Watanabe, H.; Tanaka, H.; Talanta 1978, 25, 585.

11. Nascentes, C2. C.; Arruda, M. A. Z.; Talanta 2003, 61, 759.

12. Manzoori, J. L.; Nezhad, G. K.; Anal. Sci. 2003, 19, 579.

13. Eskandari, H.; Kamali, Y.; Anal. Sci. 2004, 20, 1095.

14. Doroschuk, V. O.; Lelyushok, S. O.; Ishchenko V. B.; Kulichenko, S. A.; Talanta 2004, 64, 853.

15. Bezerra, M. A.; Conceição, A. L. B.; Ferreira, S. L. C.; Anal. Bioanal. Chem. 2004, 378, 798.

16. Wuilloud, G. M.; Wuilloud, J. C. A.; Wuilloud, R. G.; Silva, M. F.; Olsina, R. A.; Martinez, L. D.; Talanta 2002, 58, 619.
17. Chen, J.; Teo, K. C.; Anal. Chim. Acta 2001, 450, 215.

18. Chen, J.; Teo, K. C.; Anal. Chim. Acta 2001, 434, 325.

19. Lemos, V. A.; Santos, W. N. L.; Santos, J. S.; Carvalho, M. B.; Anal. Chim. Acta 2003, 481, 283.

20. Lemos, V. A.; Baliza, P. X.; Yamaki, R. T.; Rocha, M. E.; Alves, A. P. O.; Talanta 2003, 61, 675.

21. Fang, Z.; Flow Injection Separation and Preconcentration, $1^{\text {st }}$ ed., John Wiley: New York, 1993.

22. Kulichenko, S. A.; Doroschuk, V. O.; Lelyushok, S. O.; Talanta 2003, 59, 767.

23. Manzoori, J. L.; Bavili-Tabrizi, A.; Microchem. J. 2002, 72, 1.

24. Tang, A.; Jiang, D.; Yan, X.; Anal. Chim. Acta 2004, 507, 203.

25. Silva, M. A. M.; Frescura, V. L. A.; Curtius, A. J.; Spectrochim. Acta, Part B 2000, 55, 803.

Received: May 14, 2005 Published on the web: October 11, 2005 